\title{
Percutaneous closure of Waterston shunt in an adult after correction of congenital heart disease - a case report
}

Przeznaczyniowe zamknięcie czynnego zespolenia Waterstona u chorego po korekcji wrodzonej wady serca - opis przypadku

\section{Marcin Demkow ${ }^{1}$, Elżbieta Katarzyna Biernacka², Dominika Kwaśniak², Emilia Zaborowska³ ${ }^{3}$ Joanna Petryka ${ }^{14}$, Janina Stępińska3 ${ }^{3}$ Piotr Hoffman²}

1Department of Coronary Artery Disease and Structural Heart Diseases, Institute of Cardiology, Warsaw, Poland

2Department of Congenital Heart Diseases, Institute of Cardiology, Warsaw, Poland

${ }^{3}$ Department of Cardiac Intensive Care, Institute of Cardiology, Warsaw, Poland

4Magnetic Resonance Unit, Institute of Cardiology, Warsaw, Poland

\begin{abstract}
We present a 30-year-old man with a history of correction of congenital heart disease and two palliative shunts (Blalock-Taussig and Waterston), who was admitted to our hospital for worsening of heart failure. The echocardiogram showed severe pulmonary regurgitation, both ventricles hypokinetic, left ventricular ejection fraction 20\%. Magnetic resonance imaging demonstrated Waterston shunt (Qp : Qs = 3:1). The patient was symptomatic and intensive intravenous pharmacological treatment was not effective. Percutaneous closure of Waterston shunt was performed. After intervention the patient was stable on oral treatment.
\end{abstract}

Key words: Waterston shunt, congenital heart disease, percutaneous closure

\section{Streszczenie}

Przedstawiono przypadek 30-letniego pacjenta po całkowitej korekcji złożonej wrodzonej wady serca i po wcześniej wykonanych operacjach paliatywnych (zespolenie typu Blalocka-Taussig i typu Waterstona). U pacjenta przyjętego z zaostrzeniem obukomorowej niewydolności serca (NYHA IV) stwierdzano ciężką niedomykalność płucną i znacznie upośledzoną kurczliwość obu komór. Stwierdzono również duży przeciek lewo-prawy przez czynne zespolenie Waterstona (Qp : Qs = $3: 1$ ). Leczenie farmakologiczne nie było skuteczne. Wykonano przeznaczyniowe zamknięcie przecieku za pomocą okludera Amplatza. Uzyskano radykalną poprawę stanu pacjenta leczonego doustnie.

Słowa kluczowe: zespolenie Waterstona, wrodzona wada serca, zamknięcie przeznaczyniowe

\section{Introduction}

In patients with cyanotic congenital heart diseases and diminished pulmonary blood flow, palliative procedures are performed in order to increase pulmonary flow, and therefore to decrease tissue hypoxia due to direct or indirect connection of pulmonary arteries and systemic veins or systemic circulation. The Waterston shunt, first introduced in 1962, was the side-to-side anastomosis of the right pulmonary artery with the ascending aorta [1]. Because of the high complication rate and difficulties during shunt occlusion, this surgery has not been performed for many years. The most common complications of the Waterston shunt are stenosis and "bending" of the right pulmonary artery with unequal pulmonary flow, pulmonary hypertension or left ventricular failure due to long-lasting volume overload [2,3]. Currently, increasingly often, the total correction of the defect is performed without prior palliative shunt.

\section{Case report}

A thirty-year-old man with congenital heart disease composed of double outlet right ventricle, subvalvular and

Corresponding author/Adres do korespondencji:

Prof. Marcin Demkow MD, PhD, Department of Coronary Artery Disease and Structural Heart Diseases, Institute of Cardiology, 42 Alpejska, 04-628 Warsaw, Poland, tel.: +48 2234343 42, fax: +48 2234345 16, e-mail: mdemkow@ikard.pl

Praca wpłynęta: 21.06.2011, przyjęta do druku: 11.08.2011. 
valvular pulmonary stenosis and ventricular septal defect, after Waterston shunt in the $1^{\text {st }}$ year of life and BlalockTaussig shunt in the $5^{\text {th }}$ year of life, after complete correction of the disease (VSD closure with a velour patch, enlargement of the pulmonary artery using a pericardial patch, closure of the aorto-pulmonary shunts), with severe pulmonary valve regurgitation and patent Waterston shunt was admitted to the ward due to another episode of decompensated heart failure which had occurred several times in the preceding half of the year.

Physical examination revealed resting dyspnoea, hepatomegaly, ascites and peripheral oedema. Chest

Table 1. Cardiac catheterization protocol

Tabela 1. Protokót cewnikowania serca

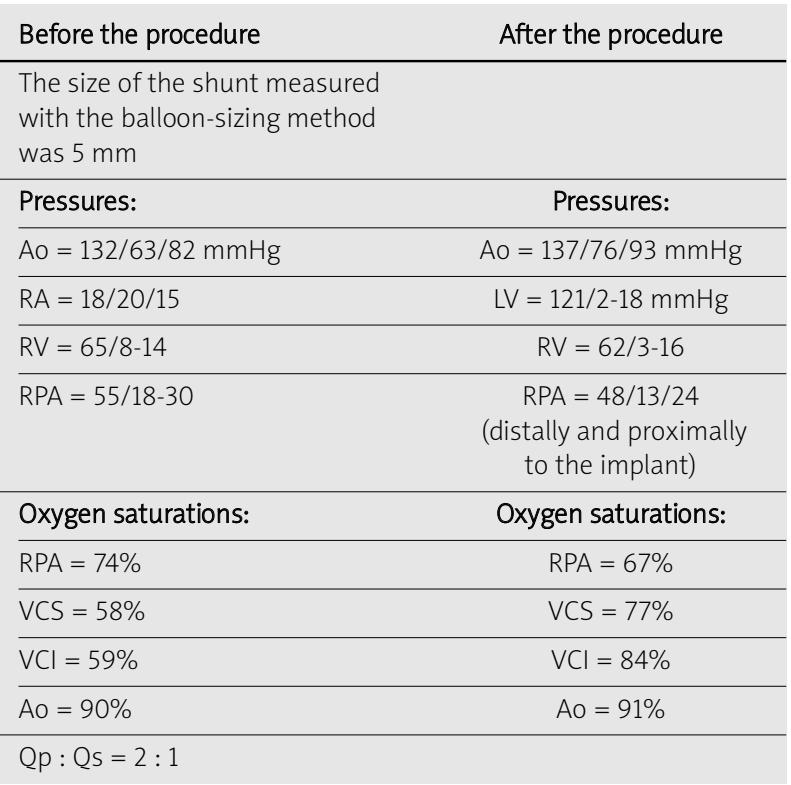

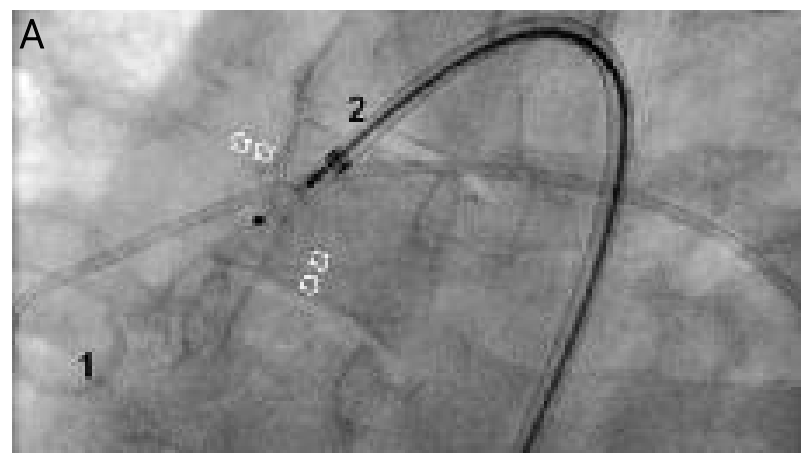

X-ray showed a massively enlarged heart, dilated pulmonary arteries and their ramifications in the pulmonary hili and a reduction of the peripheral pulmonary arterial circulation. Laboratory examinations disclosed increased hepatic markers (GPT $102 \mathrm{U} / \mathrm{l}$, GOT $68 \mathrm{U} / \mathrm{l}, \gamma$-GTP $268 \mathrm{U} / \mathrm{l}$ ) and NT-proBNP (3697 pg/ml). Echocardiographic examination showed significant pulmonary regurgitation with enlarged, hypokinetic right ventricle and dilated left ventricle (up to $6 \mathrm{~cm}$ in diastole) with global, severe hypokinesis (LVEF $=20 \%$ ).

Cardiac magnetic resonance demonstrated the presence of left-to-right systolodiastolic flow of about 50 $\mathrm{ml} /$ heart cycle through the Waterston shunt (which comprised about $60 \%$ of the left ventricular output) with $\mathrm{Qp}: \mathrm{Qs}=3: 1$. The patient required administration of intravenous diuretics (furosemide, aldactone) and catecholamines (dobutamine, dopamine). Due to lack of clinical status improvement despite intensive pharmacological treatment it was decided to perform percutaneous closure of the Waterston shunt.

To close the shunt a $5 \mathrm{~mm}$ Amplatzer Septal Occluder was introduced through the $7 \mathrm{Fr}$ delivery system via the femoral artery and was used to tightly seal the left-to-right shunt (fig. 1-3).

The patient's clinical condition improved in the following days. Catecholamines were withdrawn and an oral diuretic was introduced. The patient was discharged from the hospital in a good condition. Examinations performed 2 months after the procedure showed improvement of the left ventricular ejection fraction (LVEF = $26 \%$ ). Nevertheless, there was a persistent very low maximal oxygen uptake ( $\max . \vee V_{2}=9.2 \mathrm{ml} / \mathrm{m}^{2} / \mathrm{min}$ ). At this moment a decision regarding surgical correction of the pulmonary regurgitation has not been made.

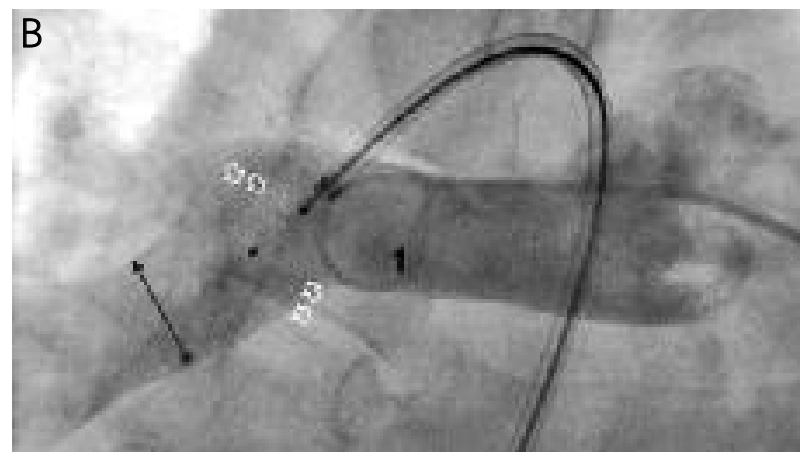

Fig. 1. A - Amplatzer Occluder immediately after implantation in the Waterston shunt location (empty arrows) before its release from the guidewire (anteroposterior view). B - The same view supplemented by right pulmonary artery angiography - wide flow of contrast without signs of artery stenosis caused by the implant. 1 - angiographic catheter in the right pulmonary artery, 2 - delivery sheath in the ascending aorta

Ryc. 1. A-okluder Amplatza bezpośrednio po wszczepieniu w miejsce zespolenia Waterstona (puste strzatki), przed odczepieniem od prowadnika (projekcja przednio-tylna). B - ta sama projekcja z angiografia prawej tętnicy płucnej - szeroki przepływ kontrastu, bez cech zwężania tętnicy przez implant; 1 - cewnik angiograficzny w prawej tętnicy płucnej, 2 - koszulka dostarczająca w aorcie wstępującej 

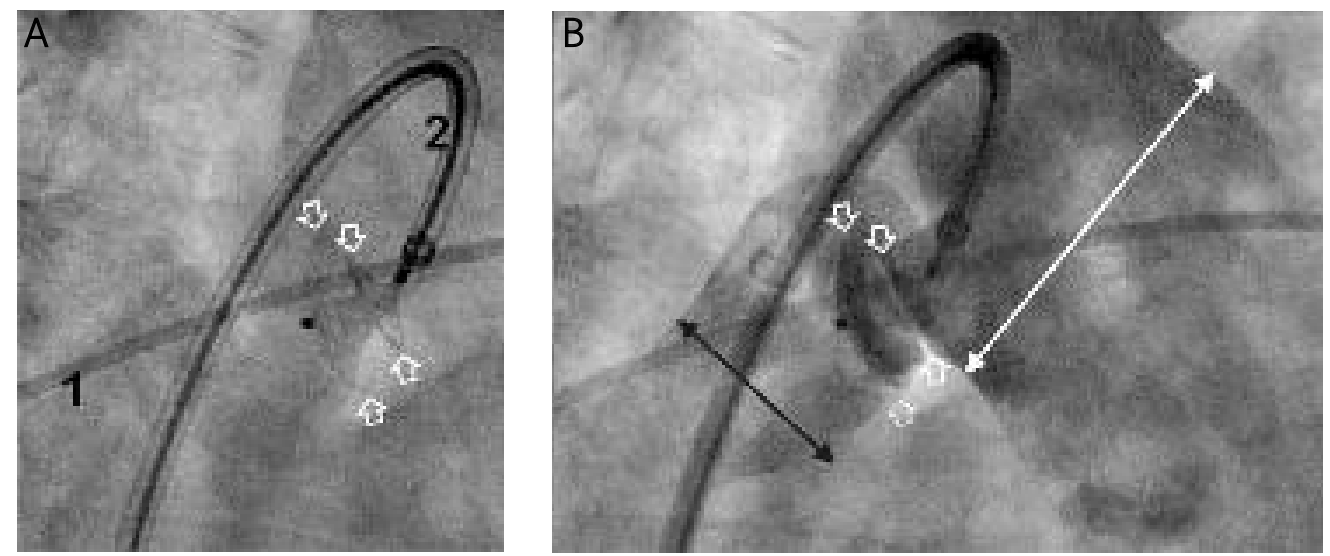

Fig. 2. A - Amplatzer Occluder directly after implantation in the Waterston shunt location (empty arrows) before its release from the guidewire (right oblique view $45^{\circ}$ ). B - the same view with the angiogram of the ascending aorta (double white arrow), contrast agent injected through the delivery sheath. 1 - angiographic catheter in the right pulmonary artery, 2 - small residual shunt to the right pulmonary artery (double black arrow) through the occluder

Ryc. 2. A-okluder Amplatza bezpośrednio po wszczepieniu w miejsce zespolenia Waterstona (puste strzatki), przed odczepieniem od prowadnika (projekcja prawoskośna $45^{\circ}$ ). B - ta sama projekcja z angiografia aorty wstępującej (biała podwójna strzałka), kontrast podany przez koszulkę dostarczającą; 1 - cewnik angiograficzny w prawej tętnicy płucnej, 2 - niewielki resztkowy przeciek do prawej tętnicy płucnej (czarna podwójna strzałka) przez siatkę okludera
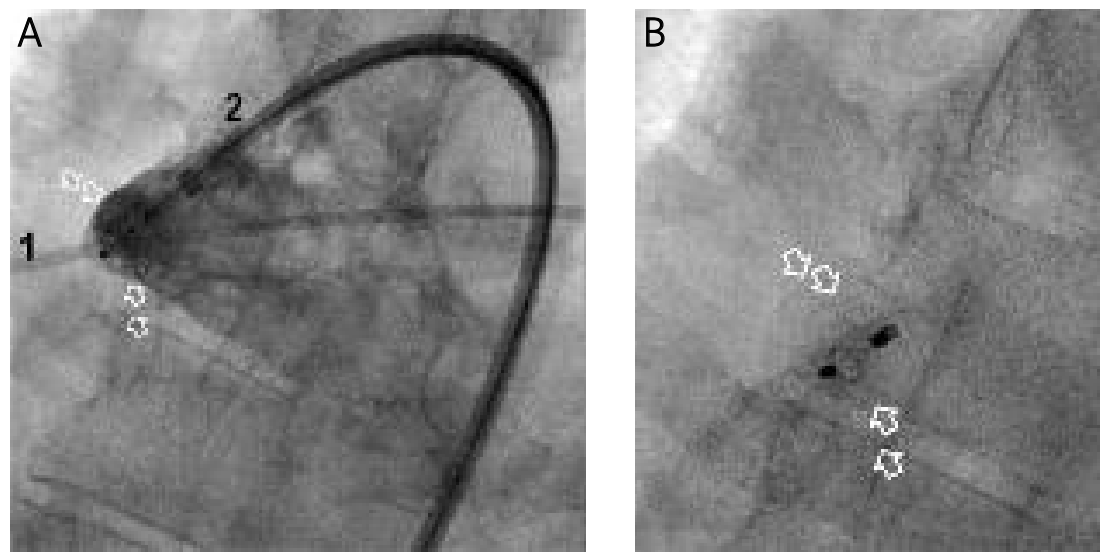

Fig. 3. A - after occluder release, contrast agent injected into the ascending aorta through the delivery sheath, no shunt to the right pulmonary artery. 1 - angiographic catheter in the right pulmonary artery, 2 - delivery sheath in the ascending aorta. B - radiographic image of the occluder closing the shunt (empty arrows). Anteroposterior view

Ryc. 3. A-po odczepieniu okludera kontrast podany do aorty wstępującej przez koszulkę dostarczająca, bez przecieku do tętnicy płucnej; 1 - cewnik angiograficzny w prawej tętnicy płucnej, 2 - koszulka dostarczająca w aorcie wstępującej. B - obraz radiologiczny okludera zamykającego zespolenie (puste strzałki). Projekcja przednio-tylna

\section{Discussion}

Waterston shunt is currently a historical method of treatment. The most frequently observed complication after this kind of procedure was pulmonary hypertension caused by increased pulmonary inflow. This was related to the fact that tailoring of the right shunt size was very difficult. Another problem consisted of asymmetric pulmonary inflow caused by bending and stenosis of the right pulmonary artery. A long-lasting left ventricular volume overload (as in congenital heart disease with coexisting shunt) caused left ventricular dilation and failure. Additional problems included difficulties in the surgical closure of the shunt [4].

In the presented case, complete correction of the congenital heart disease was performed in the $5^{\text {th }}$ year of 
life. It consisted of VSD closure using a velour patch, pulmonary artery enlargement using a pericardial patch, closure of the Blalock-Taussig shunt and an attempt to close a Waterston shunt. Several years after the correction the shunt was still patent and led to a continuous left-toright flow with a pulmonary-to-systemic ratio of $2: 1$, which caused a left ventricular volume overload. For that reason the patient was qualified for reoperation, which he refused.

In the course of several years, symptoms of severe biventricular failure developed. The patient was in a severe clinical condition and a surgical procedure could not be performed due to unacceptable risk. Heart transplantation was debated and subsequently renounced because of the high pulmonary pressure. The shunt was successfully closed percutaneously using the Amplatzer occluder. Reduction of left ventricular volume overload led to an immediate improvement of the patient's clinical condition. It was possible to withdraw intravenous diuretics and catecholamines and to introduce oral diuretics, which permitted continuation of treatment at home. Control examinations performed after 2 months showed improvement of the left ventricular ejection fraction. Percutaneous closure of the patent Waterston shunt led to stabilization of the patient's condition. Control examinations planned for the following months will demonstrate if there is a chance of continued improvement of the left ventricular function which could permit surgical treatment of the pulmonary regurgitation.

\section{References}

1. Waterston DJ. Treatment of Fallot's tatralogy in children under one year of age. Rozhl Chir 1962; 41: 181.

2. Therrien J, Webb GD. Congenital heart disease in adults. In: Braunwald E, Zipes D, Libby P (eds.) Heart disease: a textbook of cardiovascular medicine. 6th ed., Philadelphia, WB Saunders Co. 2001; 1592-1621.

3. Hoffman P, Białkowski J, Demkow M, et al. Standardy Polskiego Towarzystwa Kardiologicznego - Wady wrodzone serca u dorosłych 2000. http://www.ptkardio.pl/files/file/2000_3.

4. Wojtalik M, Henschke J, Skalski JH. Zabiegi łagodzące. http://www. kardiochirurgiadziecieca.cm-uj.krakow.pl/r17.pdf. 